\title{
Calorie Requirements for Growth after Severe Undernutrition
}

\author{
I. H. E. RUTISHAUSER and R. A. McCANCE \\ From the Medical Research Council Infantile Malnutrition Unit, Mulago Hospital, \\ Kampala, Uganda
}

There are some apparently very discordant findings in the literature about the effect of undernutrition on oxygen consumption and the metabolic requirements for subsequent growth. Difficulties began to arise more than 50 years ago when Benedict and Talbot (1914), Murlin and Hoobler (1915), and Fleming (1921) agreed in finding that, 'the heat production per kilogram body weight is higher in the malnourished or marasmic infant than in the normal infant' (Talbot, 1921). The approximate figures were 80 and $55 \mathrm{kcal} . / \mathrm{kg}$. 24 hours, respectively, and these findings were subsequently confirmed (Fleming and Hutchison, 1924; Levine, Wilson, and Gottschall, 1928; Garot, 1933; Janet and Bochet, 1933; Kerpel-Fronius et al., 1951).

These results are quite out of line with the findings in undernourished adults, who have always been found to have cold skins and subnormal resting metabolic rates per kilogram body weight (Zuntz and Loewy, 1918; Keys et al., 1950; Kerpel-Fronius, Varga, and Kun, 1954). Further confirmatory evidence was given by McCance and Mount (1960). Montgomery (1962), moreover, did not confirm them in children, for he found that on admission the resting metabolic rates were low or within normal limits. Mönckeberg et al. (1964) found the same so long as the children were not gaining weight. They rose, however, considerably during treatment, and reached figures of 60 to $90 \mathrm{kcal} . / \mathrm{kg}$. 24 hours if the weight began to rise satisfactorily. The earlier workers appear to have studied many of their cases during this phase as did Mönckeberg et al., and this may help to explain the level of their results.

The work on animals has been more consistent for, whether young or old, undernourished rats, pigs, and cockerels have always been found to have low resting metabolic rates compared with healthy normal animals of the same weight (Horst, Mendel, and Benedict, 1934; McCance and Mount, 1960;

Received July 11, 1967.
Mount, Lister, and McCance, 1963) which rose to normal on rehabilitation.

It has gradually come to be accepted (Levine et al., 1928; Waterlow, 1961; Graham, Cordano, and Baertl, 1963) that malnourished children, and particularly marasmic children, often have to be given a much higher protein and calorie intake than children of the same weight normally take before they gain weight satisfactorily, and the work on energy metabolism has frequently been invoked to explain this (Waterlow, Gopalan, Dean et al., see Waterlow, 1955). Montgomery (1962), moreover, by showing that the resting metabolic rates rose during recovery to figures well above the accepted normals for children of the same weight, appeared at the time to have confirmed this and to have overruled the findings of the few clinicians who had found that older 'marasmic' children gained weight as well as or better than normal children if they were given enough food (Tisdall, Drake, and Brown, 1925; Wang et al., 1926). Montgomery's findings, moreover, ran counter to the work on animals, for Thompson and Mendel (1918), Jackson (1937), and Mendes and Waterlow (1958) had found that malnourished rats responded normally to an increase in the necessary foodstuffs, and McCance (1960) and Mount et al. (1963) that cockerels and pigs behaved in exactly the same way.

In the hope of being able to bring some measure of order out of this chaos, we have compared the calorie intakes per gram of weight gain of marasmic and normal infants growing over approximately the same weight range.

\section{Subjects and Experimental Procedure}

Thirty-four children have been studied. All were clinical cases of severe wasting and were less than $70 \%$ of expected weight for age on the basis of a Baganda standard (Rutishauser, 1965), but without any detectable oedema. It is difficult in Uganda, where the banana is the staple article of diet, to exclude the possibility that there has not been some deficiency in the dietary 
TABLE I

Composition of the Diets per $100 \mathrm{~g}$. as Fed

\begin{tabular}{l|c|c|c|c|c|c}
\hline Diet & Calories & $\begin{array}{c}\text { Protein } \\
\text { (g.) }\end{array}$ & $\begin{array}{c}\text { Fat } \\
\text { (g.) }\end{array}$ & \multicolumn{2}{|c|}{ Carbohydrate (g.) } \\
\cline { 4 - 6 } & & & Lactose & Sucrose & Glucose \\
\hline A & 88 & $3 \cdot 9$ & $5 \cdot 9$ & $1 \cdot 6$ & $3 \cdot 1$ & - \\
B & 103 & $3 \cdot 8$ & $7 \cdot 1$ & $1 \cdot 6$ & $3 \cdot 1$ & $1 \cdot 0$ \\
C & 100 & $2 \cdot 1$ & $7 \cdot 1$ & $3 \cdot 1$ & $3 \cdot 5$ & - \\
\hline
\end{tabular}

protein/calorie ratio, but there was no evidence of this in these children and they were therefore regarded as cases of total calorie deprivation, and treated accordingly.

The subjects have been divided into three groups, $\mathrm{A}, \mathrm{B}$, and $\mathrm{C}$, containing 9,12 , and 13 children respectively, according to the diet they received. There was no statistically significant difference between the groups with respect to age, weight as a percentage of the expected weight for their age, or total serum protein on admission. Their ages ranged from 2 to 24 months, with a mean of 10 months, their weights from 36 to $68 \%$ of that expected, with a mean of $49 \%$, and total serum protein from 4.0 to $8 \cdot 4 \%$, with a mean of $5 \cdot 9 \%$.

Details of the diets are given in Table I. Group A received the diet given at that time for the treatment of kwashiorkor (Dean and Swanne, 1963), providing basically 90 calories and $4 \mathrm{~g}$. protein $/ \mathrm{kg}$. day, and supplemented according to appetite with cooked banana to give calorie intakes up to $150 / \mathrm{kg}$. day. Diet B was our first attempt to improve the treatment of marasmus and was basically similar to diet A but provided 200 calories and 7 to $8 \mathrm{~g}$. protein $/ \mathrm{kg}$. day. Diet $\mathrm{C}$ consisted of full-cream milk, sugar, and cottonseed oil and also provided 200 calories per kg. day but only $4 \mathrm{~g}$. protein. In a few children who were very hungry the diets were supplemented with small amounts of Farlene (Farley's Infant Food Ltd.).

The children were weighed daily in the morning before their 6 a.m. meal, on a Berkel Auto Scale weighing up to $14 \cdot 5 \mathrm{~kg}$. by $10 \mathrm{~g}$. divisions. They were given the diet usually on the first morning after admission and thereafter for a continuous period of at least 3 weeks, and in some children for a much longer period. Some of the children did not take the full quantity of the diets so that the calorie intakes per $\mathrm{kg}$. varied in all three groups. The gains in weight in the first few days of treatment were occasionally small and were sometimes very high, possibly due to rehydration. The changes in weight during this period have therefore been excluded, and all the figures given are for periods of 14 days starting from the beginning of the second, fourth, or sixth week of a child's stay in the ward. The temperature in our ward at 6 a.m. is usually around $25^{\circ} \mathrm{C}$. $\left(77^{\circ} \mathrm{F}\right.$.) and a little higher $26 \cdot 7^{\circ} \mathrm{C}$. $\left(80^{\circ} \mathrm{F}\right.$. $)$ at the same time in the evening.

\section{Results}

Table II gives the calorie intakes per g. weight gain for 39 two-week periods in 29 children during the first two months of treatment, and compares them with similar values calculated for Waterlow's children (1961), with values for a normal breast-fed baby. An intake of 32.5 calories/g. gain may be added for normal breast-fed infants while doubling their birthweights, i.e. over the whole of the weight range covered in Table II. This was calculated from a survey of the literature by McCance and Widdowson (1964). The figures show that over the weight range studied the calorie intakes/ g. gain of the undernourished children were not higher than those of normal children. Waterlow's children, all of whom were studied in the second and third months of treatment had, in fact, considerably lower calorie intakes per g. gain than the normal babies. Over the weight range given, all but 2 of the children in Waterlow's table were used to obtain the figures for Table II. These 2 children, both in the 4 to $5 \mathrm{~kg}$. group, had calorie intakes $/ \mathrm{g}$. gain of 65 and 72, respectively.

Table III gives information about the diet and clinical records of 8 children in this study whose calorie intakes/g. gain exceeded 50 in the second and third weeks of treatment. There were relatively more failures to gain on diet $A$ than on diets $B$ and C; 5 out of 9 on diet A and only 3 out of 25 on diets $B$ and $C$. In 4 of the 8 children in Table III, diarrhoea and (or) vomiting was responsible at one point for a loss in weight. In each of the the other 4 children there was a complicating infection. 4

TABLE II

Calorie Intakes per g. Weight Gain per Period in Undernourished and Normal Children

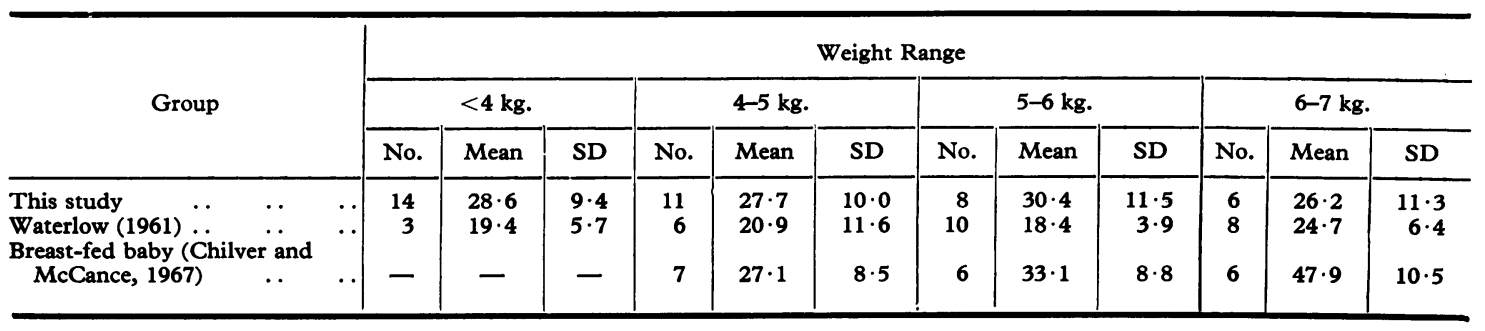


TABLE III

Diets and Associated Clinical Findings in Undernourished Children whose Calorie Intakes per g. Gain, during 2nd and 3rd Weeks of Treatment, Exceeded 50

\begin{tabular}{|c|c|c|c|}
\hline Child & $\begin{array}{l}\text { Calorie } \\
\text { Intake/ } \\
\text { g. gain }\end{array}$ & Diet & Associated Clinical Condition \\
\hline $\begin{array}{l}63 / 1 \\
64 / 2 \\
65 / 1\end{array}$ & $\begin{array}{c}\text { Lost weight } \\
224 \cdot 0 \\
63 \cdot 5\end{array}$ & $\begin{array}{l}\mathbf{A} \\
\mathbf{A} \\
\mathbf{A}\end{array}$ & $\begin{array}{l}\text { Some loose stools } \\
\text { Respiratory infection } \\
\text { Loss of } 0.5 \mathrm{~kg} \text {. associated with } \\
\text { vomiting }\end{array}$ \\
\hline $65 / 3$ & Lost weight & A & $\begin{array}{l}\text { Loss of } 0.6 \mathrm{~kg} \text {. associated with } \\
\text { diarrhoea }\end{array}$ \\
\hline $65 / 5$ & $80 \cdot 0$ & $\mathbf{A}$ & $\begin{array}{l}\text { Suspected tuberculosis-therapy } \\
\text { started on day } 16\end{array}$ \\
\hline $65 / 10$ & Lost weight & $\mathbf{B}$ & $\begin{array}{l}\text { Anaemia and heart failure requiring } \\
\text { transfusion }\end{array}$ \\
\hline $\begin{array}{l}66 / 1 \\
66 / 9\end{array}$ & $\begin{array}{c}69 \cdot 0 \\
\text { Lost weight }\end{array}$ & $\begin{array}{l}\mathbf{B} \\
\mathbf{C}\end{array}$ & $\begin{array}{l}\text { Chronic ear infection } \\
\text { Loss of } 0.25 \mathrm{~kg} \text {. associated with } \\
\text { diarrhoea }\end{array}$ \\
\hline
\end{tabular}

other children, not shown in Table III, who gained well in the initial stages of treatment, had periods of poor gain later on, and in each case an infection was involved.

Fig. 1 and 2 show the relation between the gain of weight and the calorie intake at the two different levels of protein intake. At $4 \mathrm{~g}$. protein $/ \mathrm{kg}$. there was a roughly linear relation between the gain in weight and the calorie intake over the range of 150 to 250 calories $/ \mathrm{kg}$. day. Such a relation did not exist at the level of 6 to $8 \mathrm{~g}$. protein $/ \mathrm{kg}$. day. Unfortunately there is little information at this level of

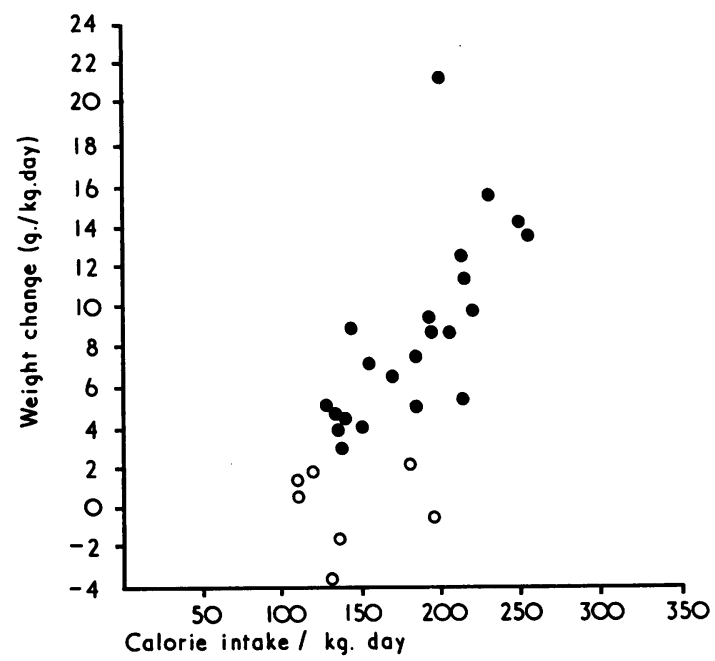

FIG. 1.-Change in weight and calorie intake of undernourished children given diets providing $4 \mathrm{~g}$. protein $/ \mathrm{kg}$. day. $\bigcirc$ Weight change associated with diarrhoea or infection. Weight change uncomplicated by infection. protein intake about the gains on calorie intakes less than $150 / \mathrm{kg}$. The stage of treatment did not affect the relation between calorie intake and weight gain, but infection or diarrhoea clearly did.

\section{Discussion}

In Uganda, in our experience marasmic children make good progress provided the infections and other interfering pathologies have been successfully treated. If the children do not gain weight, we suspect a failure on our part to diagnose the complication. A child S., for example, was admitted to our ward after prolonged unsuccessful treatments elsewhere. He had a long history of diarrhoea, vomiting, and little desire for food, and during the first few days after admission he continued to have diarrhoea on both diets $A$ and $C$. On investigation sucrose, lactose, glucose, and galactose were found in the stools and the diet was modified to exclude sugars other than fructose (Wharton, 1968; B. A. Wharton and G. R. Howells, 1967, personal communication). The diarrhoea stopped dramatically and the child at once began to gain weight. After 4 weeks the normal diet was reintroduced without any recurrence of diarrhoea. Baby N., who had also been treated elsewhere without improvement, was given a load of mixed sugars on admission which caused profuse diarrhoea, the stools containing the same sugars as in the case of child S., and the diet given from the first, therefore, contained no sugars other than fructose. The diarrhoea stopped at once, but the baby did not gain

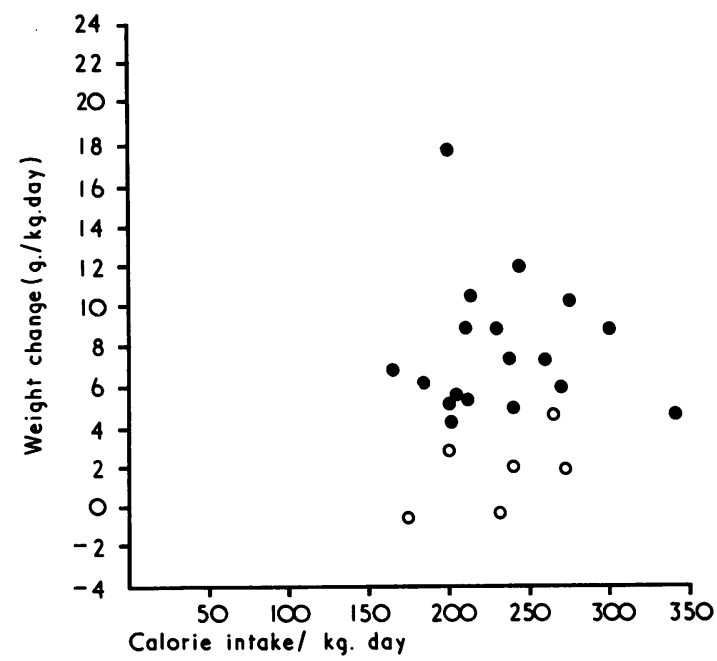

FIG. 2.-Change in weight and calorie intake of undernourished children given a diet providing 6-8 g. protein| kg. day. Symbols as in Fig. 1. 
weight and became more anaemic despite oral iron, folic acid, and B12. On day 16 she was transfused, and thereafter gained weight rapidly and the standard diet $\mathrm{C}$ was reintroduced in the fourth week.

Although the rate of gain in our children was frequently 2 to 3 times that for a normal child of the same weight, a curative improvement in weight cannot be expected in a very marasmic infant, even with uninterrupted progress, in less than 8 weeks. A child aged 8 months, for example, admitted weighing $4 \mathrm{~kg}$. (48\% of the expected weight for age) and gaining $40 \mathrm{~g}$./day for 2 months (a daily gain of 6 to $10 \mathrm{~g}$. $/ \mathrm{kg}$., i.e. about twice the normal rate for a child of the same weight) will still only be $69 \%$ of its expected weight for age at the end of that time. During a period of treatment as long as this, in a busy ward, there is always the danger of a serious intercurrent infection such as measles and, occasionally, we have even lost a patient in the third or fourth week who had till then been gaining weight very rapidly.

Our results indicate that there is no advantage in a protein intake greater than $4 \mathrm{~g}$. $/ \mathrm{kg}$. day and, in fact, at calorie intakes above $200 / \mathrm{kg}$. the children in this study receiving $4 \mathrm{~g}$. protein $/ \mathrm{kg}$. gained weight faster than those receiving larger amounts. This is in line with Waterlow's (1961) findings that, over all, given an adequate intake of protein, it is the calorie intake that determines the gain in weight in infants being treated for malnutrition.

As the calorie intake per g. gain in these children has been normal, there can be no abnormality in their metabolic rate, and there is no reason to suppose that the extra calories are required for anything more than an increased rate of 'catch-up', physiological growth. This is borne out by the fact that the children did gain weight on calorie intakes less than $150 / \mathrm{kg}$., but only at the same rate as a normal child of the same weight and, therefore, the deficit in their weight remained the same and they appeared to make no progress towards recovery.

\section{Summary}

The gains in weight of 34 children with severe wasting were studied during the first two months of treatment on diets providing calorie intakes of 100$250 / \mathrm{kg}$. day and protein intakes of 4-8 g. $/ \mathrm{kg}$. day.

The calorie intakes per $\mathrm{g}$. gain were found to be the same as those of normal children growing over the same weight range, unless the children were suffering from diarrhoea, infections, or other interfering pathologies.

There was a roughly linear relation between weight gain and calorie intake, but there were more failures to gain weight satisfactorily on the diet providing less than 150 calories/kg. day. Raising the protein intakes above $4 \mathrm{~g} . / \mathrm{kg}$. day was not beneficial.

Drs. Brian Wharton and Heather Chapman were entirely responsible for the day-to-day care of these children. Only their skill, backed by the able co-operation of Mr. Glan Howells, Miss Sheila Healy, and the nursing staff made these results possible.

\section{REFERENCES}

Benedict, F. G., and Talbot, F. B. (1914). Studies in the respiratory exchange of infants. Amer. $\mathcal{F}$. Dis. Child., 8, 1.

Chilver, J., and McCance, R. A. (1967). The food intake and growth records of a baby reared on breast milk. Nutrition (Lond.), 21, 191.

Dean, R. F. A., and Swanne, J. (1963). Abbreviated schedule of treatment for severe kwashiorkor. F. trop. Pediat., 8, 97.

Fleming, G. B. (1921). An investigation into the metabolism in infantile atrophy, with special reference to the respiratory exchange. Quart. F. Med., 14, 171.

$\longrightarrow$, and Hutchison, H. S. (1924). A study of the metabolism in the under-nourished infant. ibid., 17, 339.

Garot, L. (1933). Contribution à l'étude des troubles de métabolisme chimique dans le dénutrition grave du nourrisson. Excrétion créatinique et métabolisme basal. Rev. Franç. Pédiat., 9, 273.

Graham, G. G., Cordano, A., and Baertl, J. M. (1963). Studies in infantile malnutrition. II. Effect of protein and calorie intake on weight gain. $\mathcal{F}$. Nutr., 81, 249.

Horst, K., Mendel, L. B., and Benedict, F. G. (1934). Influence of previous diet, growth and age upon the basal metabolism of the rat. ibid., 8, 139.

Jackson, C. M. (1937). Recovery of rats upon refeeding after prolonged suppression of growth by under feeding. Anat. Rec., 68,371 .

Janet, H., and Bochet, M. (1933). Sur le métabolisme basal du nourrisson. Bull. Soc. Pédiat. (Paris), 31, 359.

Kerpel-Fronius, E., Varga, F., and Kun, K. (1954). Pathogenese der Dekomposition. II. Die Bedeutung der Anoxie, Hypothermie, und Hypoglykaemie im Endzustand der Säuglingsatrophie. Ann. paediat. (Basel), 183, 1.

$\longrightarrow,-\longrightarrow$, and Vönöczky, J. (1951). Beitrag zur Kinik und pathologischen Physiologie der Säuglingsatrophie und Dekomposition. Acta med. Acad. Sci. hung., 2, 59.

Keys, A., Brožek, J., Henschel, A., Mickelsen, O., and Taylor, H. L. (1950). The Biology of Human Starvation. University of Minnesota Press, Minneapolis.

Levine, S. Z., Wilson, J. R., and Gottschall, G. (1928). The respiratory metabolism in infancy and childhood. VIII. The respiratory exchange in marasmus : basal metabolism. Amer. $\mathcal{F}$. Dis. Child., 35, 615.

McCance, R. A. (1960). Severe undernutrition in growing and adult animals. I. Production and general effects. Brit. $\mathcal{F}$. Nutr., 14, 59.

$\longrightarrow$, and Mount, L. E. (1960). Severe undernutrition in growing and adult animals. V. Metabolic rate and body temperature in the pig. ibid., 14, 509 .

—_, and Widdowson, E. M. (1964). Protein metabolism and requirements in the newborn. In Mammalian Protein Metabolism, Vol. 2, p. 227. Ed. by H. N. Munro and J. B. Allison. Academic Press, New York.

Mendes, C. B., and Waterlow, J. C. (1958). The effect of a lowprotein diet, and of refeeding, on the composition of liver and muscle in the weanling rat. Brit. $\mathcal{F}$. Nutr., 12, 74.

Mönckeberg, F., Beas, F., Harwitz, I., Dabancens, A., and González, M. (1964). Oxygen consumption in infant malnutrition. Pediatrics, 33, 554.

Montgomery, R. D. (1962). Changes in the basal metabolic rate of the malnourished infant and their relation to body composition. f. clin. Invest., 41, 1653.

Mount, L. E., Lister, D., and McCance, R. A. (1963). Severe undernutrition in growing and adult animals. 11. The first effects of rehabilitation on the metabolic rate and body temperature. Brit. F. Nutr., 17, 407. 
Murlin, J. R., and Hoobler, B. R. (1915). The energy metabolism of ten hospital children between the ages of two months and one year. Amer. F. Dis. Child., 9, 81.

Rutishauser, I. H. E. (1965). Heights and weights of middle class Baganda children. Lancet, 2, 565.

Talbot, F. B. (1921). Severe infantile malnutrition. The energy metabolism with the report of a new series of cases. Amer. $\mathcal{F}$. Dis. Child., 22, 358.

Thompson, H. B., and Mendel, L. B. (1918). An experimental study of alternating growth and suppression of growth in the albino mouse, with special reference to the economy of food consumption. Amer. F. Physiol., 45, 431.

Tisdall, F. F., Drake, T. G. H., and Brown, A. (1925). The carbohydrate metabolism of the marantic infant. Amer. $\mathcal{F}$. Dis. Child., 30, 829.
Wang, C. C., Frank, M., Hays, B. B., and Kern, R. (1926). Metabolism of undernourished children. ibid., 32, 63.

Waterlow, J. C. (1955). (Editor.) Protein Malnutrition. Proceedings of a conference in Famaica (1953) sponsored jointly by the F.A.O., W.H.O., and fosiah Macy Fr. Foundation. University Press, Cambridge.

- (1961). The rate of recovery of malnourished infants in relation to the protein and calorie levels of the diet. $\mathcal{F}$. trop. Pediat., 7, 16.

Wharton, B. A. (1968). In Glaxo Conference on Calorie Deficiencies and Protein Deficiencies. Ed. by R. A. McCance and E. M. Widdowson. Churchill, London.

Zuntz, N., and Loewy, A. (1918). Weitere Untersuchungen über den Einfluss der Kriegskost auf den Stoffwechsel. Biochem. Z., 90, 244.

The following articles will appear in future issues of this Journal:

Raynaud's Disease Treated with Griseofulvin. By R. D. G. Creery, M. A. Voyce, A. W. Preece, and A. R. Evason.

Studies in Mental Handicap-II. By C. M. Drillien.

Review Article: Ventricular Septal Defect: A Review of Current Thoughts. By A. S. Nadas and D. C. Fyler.

Hypo-hyperparathyroidism. By E. H. Allen, F. J. C. Millard, and J. R. Nassim.

Estimation of Gestational Age by Neurological Assessment in First Week of Life. By V. Farr.

Diagnosis of Coeliac Disease in Retrospect. By A. S. McNeish.

Umbilical Artery Catheterization in the Newborn. By J. M. Gupta, N. R. C. Roberton, and J. S. Wigglesworth.

In Vivo Penetration of Antibiotics into Sputum in Cystic Fibrosis. By B. A. Saggers and D. Lawson. Branching Enzyme-deficiency Glycogenosis; Studies in Therapy. By J. Fernandes and F. Huijing.

Desferrioxamine in Thalassaemia. By M. Diwany, M. Gabr, A. El Hefni, and N. Mokhtar.

Evaluation of the Deficiency of 21-Hydroxylation in Patients with Congenital Adrenal Hyperplasia. By O. M. Galal, B. T. Rudd, and N. M. Drayer.

Hepatic Coma with Renal Failure, Treated by Repeated Exchange Transfusion. By E. N. Thompson, J. Cawdery, and J. Martin.

Personal Practice: Ventilating the Lungs of Newborn Infants for Prolonged Periods. By M. E. Tunstall, J. I. Cater, J. S. Thomson, and R. G. Mitchell.

Urinary Vanillyl-mandelic Acid Excretion by Chronically Anaemic Children. By N. Matsaniotis, N. Beratis, and C. Economou-Mavrou.

Plasma Cortisol Levels in Protein-calorie Malnutrition. By K. S. Jaya Rao, S. G. Srikantia, and C. Gopalan. 